\title{
ANALISA PRODUK TABUNGAN BSM DALAM MENARIK MINAT NASABAH
}

(Studi Pada PT. Bank Syariah Mandiri Kantor Cabang Pembantu Dumai Sukajadi)

\author{
Khodijah Ishak, Ida Afrida Ningsih \\ Sekolah Tinggi Ilmu Ekonomi (STIE) Syariah Bengkalis \\ khodijahishak2@gmail.com, idaafrida.ningsih@ymail.com
}

\begin{abstract}
Bank Syariah Mandiri Dumai Sukajadi Sub-Branch Office is one of the banks operating based on sharia principles offering fundraising products and one of them is tabungan BSM. The tabungan BSM are based on sharia principles with the mudharabah muthlaqah agreement. This research uses primary data and secondary data. The results showed that the marketing strategy of tabungan BSM products to attract customers of Bank Syariah Mandiri Dumai Sukajadi SubBranch Office has been going well, from conducting promotions, socializing, distributing brochures and participating in certain events. In addition, the presence of Bank Syariah Mandiri Dumai Sukajadi Sub-Branch Office is very helpful for customers to open various kinds of savings provided by the Bank Syariah Mandiri Dumai Sukajadi Sub-Branch Office.
\end{abstract}

Keywords: Tabungan BSM, Customer Interest, Bank Syariah Mandiri.

\begin{abstract}
ABSTRAK
Bank Syariah Mandiri Kantor Cabang Pembantu Dumai Sukajadi merupakan salah satu Bank yang beroperasi berdasarkan prinsip syariah yang menawarkan produk penghimpunan dana dan penyaluran dana salah satunya adalah tabungan BSM. Tabungan BSM ini berdasarkan prinsip syariah dengan akad mudharabah muthlaqah. Penelitian ini menggunakan data primer dan data sekunder. Hasil penelitian menunjukkan bahwa strategi pemasaran produk tabungan BSM untuk menarik minat nasabah Bank Syariah Mandiri Kantor Cabang Pembantu Dumai Sukajadi sudah berjalan dengan baik, dari melakukan promosi, sosialisasi, penyebaran brosur dan mengikuti event-event tertentu. Selain itu keberadaan Bank Syariah Mandiri Kantor Cabang Pembantu Dumai Sukajadi ini sangat membantu nasabah untuk membuka berbagai macam tabungan yang disediakan oleh Bank Syariah Mandiri Kantor Cabang Pembantu Dumai Sukajadi.
\end{abstract}

Kata kunci: Tabungan BSM, Minat Nasabah, Bank Syariah Mandiri.

\section{PENDAHULUAN}

Islam merupakan ajaran yang mengetahui kehidupan dalam dimensi akidah, ibadah dan semua bentuk transaksi, khususunya pada hal-hal yang berkaitan dengan masalah ekonomi (At-Tariqi 2004, 1). Dalam bidang ekonomi, islam menetapkan aturan komprehensif tentang keterkaitan antara dua orang yang melakukan transaksi melalui dengan adanya hukum agama tentang masalah itu. 
Aturan itu merupakan rambu-rambu tentang bagaimana mencari dan mengembangkan harta sekaligus pengalokasian dan pembelanjaanya.

Menurut Undang-undang RI nomor 10 tahun 1998 tanggal 10 November 1998 tentang perbankan adalah Badan usaha yang menghimpun dana dari masyarakat dalam bentuk simpanan dan menyalurkan kembali kepada masyarakat dalam bentuk kredit atau dalam bentuk-bentuk lainnya dalam rangka meningkatkan taraf hidup rakyat banyak (Kasmir. 2003, 23).

Bank syariah merupakan suatu lembaga keuangan yang berlandasan AlQur'an dan Hadist ataupun sesuai dengan prinsip Syariah. Dalam menjalankan tuganya bank syariah hanya melakukan berdasarkan prinsip Syariah. Sebagaimana prinsip Syariah itu sendiri, dan sesuai dengan Visi dan Misi Perbankan Syariah umumnya adalah menjadi wadah terpecaya bagi masyarakat yang ingin menabung dengan sistem bagi hasil di Bank Syariah. Memenuhi rasa keadilan bagi semuapihak dan memberikan maslahat bagi masyarakat luas.

Dalam menarik minat nasabah, Bank haruslah benar-benar peka terhadap keinginan dan kebutuhan masyarakat, dengan cara melakukan berbagai macam strategi yang bisa menarik hati masyarakat untuk menjadi nasabah. Salah satu sumber dana dari pihak ketiga yaitu tabungan memiliki peran yang sangat penting dalam menarik dana bagi Bank dari masyarakat, karena tabungan lebih banyak dikenal oleh masyarakat dan bisa digunakan atau dinikmati manfaatnya oleh semua golongan masyarakat. Kehadiran Bank Konvesional yang telah lebih dikenal dahulu mengambil tempat dihati masyarakat merupakan suatu tantangan bagi Bank Syariah untuk merebut hati masyarakat dengan memperkenalkan produk-produk tabungan yang berdasarkan Syariah Islam.

Dengan menangani permasalahan ekonomi umat islam, maka perlulah wadah yang baik untuk mendukung perekonomian umat islam. Sehubungan dengan hal tersebut, seperti yang kita ketahui bersama bahwa perbankan syariah mempunyai berbagai macam produk yang ditawarkan kepada nasabah, seperti tabungan, bagi hasil, jual beli, sewa, dan jasa. Dalam hal ini produk tabungan yang ditawarkan oleh Bank Syariah Mandiri adalah tabungan BSM, tabungan BSM berencana, tabungan BSM simpatik, tabungan BSM investa cendikia, BSM tabungan mabrur, dan TabunganKu. Disini penulis menyadari dengan segala, keterbatasan pengetahuan dan kemampuan maka penulis lebih mengkhususkan pada produk tabungan BSM.

Tabungan itu sendiri menurut undang-undang perbankan nomor 10 tahun 1998 adalah simpanan yang penarikannya hanya dapat dilakukan menurut syaratsyarat tertentu yang disepakati, tetapi tidak dapat ditarik dengan cek, bilyet giro dan atau alat lainnya yang dipersamakan dengan itu (Kasmir. 2003, 74). Manakala tabungan BSM merupakan tabungan dalam mata uang rupiah yang penarikan dan penyetorannya dapat dilakukan setiap saat selama jam buka kas di konter BSM atau melalui ATM. Adanya perbankan Syariah yang menawarkan produk tabungan BSM ini, dengan menggunakan akad mudharabah muthlaqah.

Untuk menghindari masyarakat islam terlibat dalam kebiasan Riba maka PT Bank Syariah Mandiri Kantor Cabang Pembantu Dumai Sukajadi diresmikan pada tanggal 28 Oktober 2011. Dan PT Bank Syariah Mandiri Kantor Cabang Pembantu Dumai Sukajadi mulai beroperasi pada tanggal 10 November 2011 dan saat itu lah Bank Syariah Mandiri Kantor Cabang Pembantu Dumai Sukajadi mulai memperkenalkan produknya kepada masyarakat Dumai setempat. PT Bank 
Syariah Mandiri KCP Dumai Sukajadi merupakan Kantor Cabang Pembantu dan merupakan Group dari Cabang Dumai dan sebelumnya merupakan sebuah KLS (Kantor Layanan Syariah) yang terdapat di Bank Mandiri Cabang Sultan Syarif Kasim Dumai, kemudian ditingkatkan statusnya menjadi Bank Syariah Mandiri Kantor Cabang Pembantu Dumai Sukajadi.

Tujuan penelitian ini adalah untuk mengetahui strategi pemasaran produk tabungan BSM dalam menarik minat nasabah nasabah pada PT Bank Syariah Mandiri Kantor Cabang Pembantu Dumai Sukajadi. Kemudian untuk melihat bagaimana perkembangan produk Tabungan BSM dalam menarik minat nasabah pada PT Bank Syariah Mandiri Kantor Cabang Pembantu Dumai Sukajadi.

\section{TELAAH LITERATUR}

\section{Tabungan}

Tabungan menurut Undang-Undang perbankan nomor 10 tahun 1998 adalah simpanan yang penarikannya hanya dapat dilakukan menurut syarat-syarat tertentu yang disepakati, tetapi tidak dapat ditarik dengan cek, bilyet giro dan atau alat lainnya yang dipersamakan dengan itu. Syarat-syarat penarikannya tertentu maksudnya adalah sesuai dengan perjanjian atau kesepakatan yang telah dibuat antara bank dengan sipenabung. Kemudian dalam hal sarana atau alat penarikannya juga tergantung dengan perjanjian antara keduanya. Hal ini tergantung dari persyaratan bank masing-masing, mau menggunakan sarana yang mereka inginkan. Alat ini dapat digunakan sendiri-sendiri atau secara bersama. Alat yang sering digunakan adalah buku tabungan, slip setoran, kartu yang terbuat dari plastik, kombinasi (kwitansi) (Kasmir. 2003, 74).

Aktivasi perbankan yang pertama adalah menghimpun dana dari masyarakat luas yang dikenal dengan istilah didunia perbankan adalah kegiatan funding. Pengertian menghimpun dana maksudnya adalah mengumpulkan atau mancari dana dengan cara mambeli dari masyarakat luas (Kasmir. 2003, 24). Bagi bank yang berdasarkan prinsip syariah tidak dikenal istilah bunga dalam memberikan jasa kepada penyimpanan maupun peminjam. Dibank ini jasa bank yang diberikan disesuaikan dengan prinsip syariah sesuai dengan hukum islam. Prinsip syariah yang diterapkan oleh bank syariah adalah pembiayaan berdasarkan prinsip bagi hasil (mudharabah) (Kasmir. 2003, 25).

Prinsip syariah tabungan diatur dalam Fatwa Dewan Syariah Nasional No.: 02/DSN-MUI/IV/2000 tentang tabungan. Tabungan ada dua jenis yaitu tabungan yang tidak dibenarkan secara syariah, yaitu tabungan yang berdasarkan perhitungan bunga, dan tabungan yang dibenarkan, yaitu tabungan yang berdasarkan prinsip wadi'ah dan mudharabah (Mukhtar 2012).

\section{Tabungan BSM}

Merupakan Tabungan dalam mata uang rupiah dengan akad Mudharabah Muthlaqah yang penarikan dan penyetorannya dapat dilakukan setiap saat selama jam buka kas di konter Bank Syariah Mandiri atau melalui ATM. Tabungan BSM ini merupakan tabungan unggulan dalam Bank Syariah Mandiri, dikarenakan produk tabungan BSM ini merupakan produk utama dalam Bank Syariah Mandiri. Tabungan BSm ini juga merupakan produk tabungan yang pertama kali yang ada di Bank Syariah Mandiri ini, sehingga itu lah dinamakan produk 
tabungan BSM. Keunggulan tabungan BSM dibandingkan dengan tabungan lainnya adalah tentunya berdasarkan prinsip Syariah dengan akad mudharabah muthlaqah dengan sistem bagi hasil dan nisbah bagi hasil yang lebih tinggi sebesar $15 \%$ dibandingkan dengan tabungan simpatik dan tabunganKu, dilengkapi dengan ATM.

Bank Syariah Mandiri menawarkan tabungan ini dengan setoran minimum awal Rp80.000, dan berdasarkan prinsip syariah dengan akad mudhrabah muthlaqah. Manfaat dan karakteristik dari tabungan ini adalah: (a) Aman dan terjamin. (b) Online di seluruh outlet BSM. (c) Bagi hasil yang kompetitif. (d) Fasilitas BSM Card yang berfungsi sebagai kartu ATM dan debit. (e) Fasilitas eBanking yaitu BSM Mobile Banking dan BSM Net Banking. (f) Berdasarkan prinsip syariah dengan akad mudharabah muthlaqah.

\section{Mudharabah Muthlaqah}

Dalam mudharabah muthlaqah tidak ada pembatasan bagi bank dalam menggunakan dana yang dihimpun. Nasabah tidak memberikan persyaratan apa pun kepada bank, ke bisnis apa dana yang disimpannya itu hendak disalurkan, atau menetapkan penggunaan-penggunaan akad tertentu, atau mensyaratkan dananya diperuntukkan bagi nasabah tertentu. Jadi bank memiliki kebebasan penuh untuk menyalurkan dana mudharabah muthlaqah ini ke bisnis manapun yang diperkirakan menguntungkan. Dari penerapan mudharabah muthlaqah ini dikembangkan produk tabungan dan deposito, sehingga terdapat dua jenis penghimpun dana, yaitu tabungan mudharabah dan tabungan deposito mudharabah. Ketentuan umum dalam pokok ini adalah: (a) Bank wajib memberitahukan kepada pemilik dana mengenai nisbah dan tata cara pemberitahuan keuntungan atau pembagian keuntungan secara resiko yang dapat ditimbulkan dari penyimpanan dana. Apabila telah tercapai kesepakatan, maka hal tersebut harus dicantumkan dalam akad. (b) Untuk tabungan mudharabah, bank dapat memberikan buku tabungan sebagai bukti penyimpanan, serta kartu ATM dan atau alat penarikan lainnya kepada penabung. Untuk deposito mudharabah, bank wajib memberikan sertifikat atau tanda penyimpanan (bilyet) deposito kepada deposan. (c) Tabungan mudharabah dapat diambil setiap saat oleh penabung sesuai dengan perjanjian yang disepakati, namun tidak diperkenankan mengalami saldo negatif. (d) Deposito mudharabah hanya dapat dicairkan sesuai dengan jangka waktu yang telah disepakati. Deposito yang diperpanjang, setelah jatuh tempo akan diperlakukan sama seperti deposito baru, tetapi bila pada akad sudah dicantumkan perpanjangan otomatis maka tidak perlu dibuat akad baru. (e) Ketentuan-ketentuan yang lain yang berkaitan dengan tabungan dan deposito tetap berlaku sepanjang tidak bertentangan dengan prinsip syariah (Karim 2014, 107).

\section{Strategi Pemasaran Produk}

Strategi pemasaran produk terdapat beberapa tahap yaitu (Swastha dan Irawan 2002, 223): (1) Tahap Perkenalan, tahap ini ditandai dengan pertumbuhan penjualan yang lambat. Pertumbuhan yang lambat disebabkan karena: (a) Kelambatan dalam perluasan kapasitas produksi, (b) Masalah teknis, (c) Kelambatan dalam penyediaan produk tersebut untuk konsumen, terutama dibidang distribusi melalui pengecer, (d) Keseganan konsumen untuk mengubah pola kebiasaan yang sudah berjalan. Adapun strategi dalam tahap perkenalan ini 
adalah: (i) Stretegi profit tinggi, merupakan strategi pemasaran dengan menetepkan harga tinggidan promosi tinggi. (ii) Strategi penetrasi premetif, dalam strategi premetif harga dikenakan rendah tetapi tingkat promosinya tinggi. (iii) Strategi penetrasi selektif, harga tinggi dan tingkat promosi yang rendah dikenakan pada strategi ini. (iv) Strategi profit rendah, merupakan strategi pemasaran yang menitik beratkan pada pengenaan harga rendah dan tingkat promosi yang rendah pula.

(2) Tahap Pertumbuhan, tahap pertumbuhan ini ditandai dengan: (a) Adanya pesaing baru yang mulai memasuki pasar. Hal ini disebabkan karena pesaing tertarik pada kesempatan bisnis yang ada maupun labanya, (b) Perusahaan mulai mengadakan perbaikan-perbaikan terhadap produknya ataupun menambah kelengkapan segi produk yang ada, (c) Harga produk tersebut cenderung untuk tetap. Namun demikian ada kemungkinan harga akan turun sedikit karna adanya persaingan, (d) Kegiatan promosi, terutama periklanan dapat dikurangi. Tetapi, munculnya pesaing-pesaing baru memaksa perusahaan untuk meningkatkan promosi meskipun hanya sedikit, (e) Penjualan segera meningkat secara cepat. Bertambahnya penjualan cepat ini dapat menurunkan rasio promosi terhadap penjualannya, sehingga akan menaikkan laba pada periode tersebut.

(3) Tahap Kedewasaan, jika perusahaan tidak melakukan perbaikanperbaikan terhadap produknya maupun tidak melakukan usaha-usaha lain yang dapat menaikkan penjualan, maka volume penjualan mencapai cenderung untuk tetap, bahkan pada akhirnya menurun. Ditinjau lebih jauh tahap kedewasaan ini dapat dibagi menjadi tiga tahap yaitu: (a) Tahap Kedewasaan yang Meningkat, pada tahap ini penjualan total meningkat dengan lambat, kelambatan ini disebabkan karena sebagian permintaan bearasal dari langganan (pembeli lama), sedangakan pembeli baru yang masuk hanya sedikit. (b) Tahap Kedewasaan yang Stabil, tahap kedewasaan yang stabil ini disebut pula tahap kejenuhan. Sekarang volume penjualan sudah tidak meningkat lagi tetapi konstan. Ini disebabkan karena seluruh permintaannya dari pembeli lama/langganan. Jadi sudah tidak ada lagi pembeli baru yang masuk. (c) Tahap Kedewasaan yang Menurun, pada tahap ini tingkat penjualan ini secara absolut mulai menurun. Hal ini disebabkan karena beberapa langganan sudah mulai meningggalkan produk perusahaan dan membeli produk lain (produk saingan termasuk produk pengganti). Jadi, sebagian langganan sudah tidak berminat lagi terhadap produk perusahaan. Strategi pemarasan yang ditempuh dalam tahap kedewasaan ini dapat dibagi menjadi 3 macam yaitu: (i) Modifikasi pasar, disini perusahaan berupa menemukan pembelipembeli baru bagi produknya. (ii) Modifikasi produk, modifikasi produk dilakukan dengan cara mengubah sifat-sitaf produk yangdapat menarik para pemakai/pembeli baru. (iii) Modifikasi Marketing-Mix, strategi terakhir yang dapat dilakukan untuk produk yang sudah mengalami tahap kedewasaan adalah Marketing-Mix. Manajer mempertimbangkan untukmengubah elemen-elemen Marketing-Mix untuk mendorong penjualannya.

(4) Tahap kemunduran, tahap terakhir yang dialami oleh suatu produk dalam siklus kehidupannya adalah tahap kemunduran. Panjang lamanya tahap kemunduran ini ditentukan oleh beberaapa faktor yaitu: (a) Perubahan dalam selera konsumen, (b) Perubahan kegiatan pesaing, (c) Kebijaksanaan meninggalkan produk oleh perusahaan. Stretegi pemasaran yang dapat dilakukan dalam tahap ini adalah: (i) Mencari produk yang lemah, strategi ini sangat penting 
bagi perusahaan yang menghasilkan beberapa macam produk. (ii) Membangkitkan lagi produk tersebut, meningkatkan usaha-usaha variabel Marketing-Mix yang dapat meneruskan untuk menghasilkan laba. (iii) Meninggalkan produk tersebut, membiarkan saja dan menunggu sampai tidak ada pembelinya dan menjual produk tersebut kepada perusahaan lain dengan cara lisensi.

\section{METODE PENELITIAN}

Penelitian ini dilakukan pada PT. Bank Syariah Mandiri (BSM) Kantor Cabang Pembantu Dumai Sukajadi. Jalan Pangeran Diponegoro No. 182 Kelurahan Rimba Sekampung Kota Dumai. Jenis data yang digunakan dalam penelitian ini adalah data kualitatif dan kuantitatif. Teknik pengumpulan data yang digunakan adalah wawancara, dokumentasi dan kepustakaan. Metode yang digunakan dalam penelitian ini adalah metode deskriptif.

\section{HASIL DAN PEMBAHASAN PENELITIAN}

\section{Strategi Pemasaran Produk Tabungan BSM Dalam Menarik Minat Nasabah}

Bank Syariah Mandiri merupakan suatu lembaga keuangan, yang mana merupakan suatu wadah untuk memperoleh pembiayaan. Bank Syariah Mandiri yang tepatnya ada di Dumai Sukajadi di sambut baik terhadap masyarakat kota Dumai. Karena mengingat di kota Dumai merupakan salah satunya berdiri perbankan yang berbasis Syariah.

Produk yang ada di Bank Syariah Mandiri Kantor Cabang Pembantu Dumai Sukajadi cukup banyak seperti tabungan BSM, tabungan investa cendikia, tabungan simpatik, tabungan mabrur dan tabungan berencana.

Tabungan BSM yang ada di Bank Syariah Mandiri Kantor Cabang Pembantu Dumai Sukajadi merupakan produk unggulan dalam perbankan Syariah. Strategi merupakan suatu tindakan atau usaha yang dilakukan untuk mencapai tujuan tertentu. Strategi yang dilakukan berbeda-beda dalam usahanya untuk mendapatkan keuntungan ataupun untuk menarik minat masyarakat sehingga masyarakat berminat untuk menabung atau bertransaksi dengan Bank tersebut.

Setiap Bank haruslah melakukan upaya yang gencar dalam hal menarik hati masyarakat untuk menabung. Dalam hal ini pihak Bank tentunya telah menargetkan untuk mendapatkan nasabah sebanyak-banyaknya agar tujuan dari targetnya bisa tercapai. Disini pihak Bank harus benar-benar bisa menargetkan bahwa dalam satu hari harus bisa mendapatkan 3 orang calon nasabah. Tentunya jika dilihat dari hal tersebut dalam pertahunnya pihak Bank harus mendapatkan calon nasabah baru sebanyak 879 orang nasabah. Semakin banyak nasabah yang dimiliki oleh Bank, maka semakin besar pulalah dana yang mungkin dimiliki oleh Bank, dan semakin besar juga dana yang bisa dimanfaatkan oleh bank untuk pembiayaan. Semakin banyak pembiayaan yang dilakukan Bank, maka kemungkinan perolehan laba akan semakin besar.

Atas dasar inilah Bank Syariah Mandiri Kantor Cabang Pembantu Dumai Sukajadi dalam melakukan strategi dalam usahanya menarik minat nasabah. Strategi-strategi tersebut adalah: (1) Melakukan sosialisasi, sosialisasi merupakan 
suatu cara memperkenalkan produk dengan cara menjelaskan dan memaparkan dihadapan masyarakat agar apa yang disampaikan oleh pihak Bank mudah di mengerti dan di pahami oleh masyarakat. Sebelum melakukan sosialisasi ini tentunya pihak Bank sudah terlebih dahulu menentukan sasaran yang akan di tuju agar apa yang di rencanakan sesuai dengan yang di inginkan. Sosialisasi ini dilaksanakan tidak hanya satu tempat saja, namun dilaksanakan dibeberapa tempat yaitu seperti di sekolah, dikantor-kantor, dan perusahan (lembaga). Dalam hal mensosialisasikan produk bank tersebut pihak bank tidak hanya bersosialisasi di sekolah maupun di kantor-kantor saja, tetapi pihak bank juga melakukan sosialisasi dipendesaan maupun diperkampungan, sehingga dengan itu masyarakat pendesaan dapat mengerti dan dapat memahami tentang Produk Tabungan BSM tersebut. Karena masih banyaknya masyarakat pendesaan maupun perkampungan belum sepenuhnya mengetahui bagaimana kinerja dan produk apa yang dimiliki oleh suatu Bank pada umumnya. Selain itu juga, disamping belum banyaknya sosialisasi dari pihak Bank masyarakat pendesaan maupun perkampungan masih takut dalam menyimpan uangnya di Bank dikarenakan masih tingginya tingkat ketakutan yang dimiliki masyarakat terhadap penipuan. Oleh sebab itu dengan adanya sosialisasi tersebut dapat membantu masyarakat untuk mengetahui bagaimana kinerja sebuah Bank, secara tidak langsung dengan bersosialisasi dapat menarik minat nasabah kususnya dipendesaan maupun diperkampungan tersebut. Dengan menggunakan strategi sosialisasi ini pihak Bank dapat menarik calon nasabah hingga $80 \%$, dikarenakan sosialisasi ini pihak Bank menjelaskan tentang produk Bank tersebut secara menyeluruh. Sosialisasi ini dilakukan seminggu sekali maupun sebulan dua kali .

(2) Penyebaran brosur, ini juga merupakan salah satu cara yang dilakukan pihak Bank dalam menarik minat nasabah. Dalam Hal ini dilakukan dengan cara pihak Bank terjun langsung kelapangan. Dalam penyebaran brosur ini dilakukan dipersimpangan jalan seperti dilampu merah. Penyebaran brosur ini juga dapat dilakukan oleh pihak Bank kepada masyarakat yang ada diperkampungan, dikarenakan masyarakat yang ada diperkampungan pada umumnya tidak selalu keluar diperkotaan disebabkan karena jarak yang ditempuh dari perkampungan tersebut sangatlah jauh dan jalan yang ditempuh juga sangatlah susah sehingga masyarakat yang ada diperkampungan kurangnya pengetahuan tentang adanya brosur yang disebarkan oleh pihak Bank. Jika dilihat dalam penyebaran brosur ini walaupun tidak begitu banyak dalam menarik minat nasabah pihak Bank masih bisa menarik minat nasabah hingga $40 \%$.

(3) Buka stand pada saat event-event tertentu, Bank Syariah Mandiri Kantor Cabang Pembantu Dumai Sukajadi ini juga tidak kalah dan tidak ketinggalan dalam mengikuti acara buka stand pada saat event-event ini. Hal ini dilakukan pihak Bank agar pihak bank bisa memperkenalkan produknya, tentunya hal ini mempunyai pengaruh yang besar untuk mendapatkan nasabah baru. Bank Syariah Mandiri Kantor Cabang Pembantu Dumai Sukajadi ini membuka stand pada saat tertentu seperti Dumai Exspo dan pameran. Dengan adanya buka stand seperti Dumai Ekspo pihak Bank dapat menarik minat nasabah hingga 50\%.

(4) Promosi, ini juga merupakan suatu cara memasarkan produk-produk yang ada di Bank. Promosi ini bertujuan untuk mengenalkan produk perbankan kepada nasabah dan juga berusaha menarik hati nasabah dan mempengaruhi hati nasabah. Dalam kegiatan promosi ini pihak Bank berusaha mempromosikan 
seluruh produk dan jasanya baik langsung maupun tidak langsung. Promosi ini tetap saja masih dilakukan lewat radio, iklan, maupun brosur. Promosi ini merupakan strategi yang paling berpengaruh terhadap peningkatan jumlah nasabah pada PT Bank Syariah Mandiri Kantor Cabang Pembantu Dumai Sukajadi. Dengan menggunakan strategi promosi pihak Bank tidak begitu banyak dalam menarik minat nasabah, tetapi pihak Bank masih memperoleh 10\% nasabah yang berminat melalui promosi tersebut.

Dari ke empat strategi diatas dapat dikatakan bahwa strategi sosialisasilah yang sangat berhasil dalam menarik minat nasabah, dikarenakan strategi sosialisasi ini sangat banyak mendapatkan respon positif oleh masyarakat banyak, baik di perkotaan maupun di pendesaan.

\section{Perkembangan Produk Tabungan BSM Dalam Menarik Minat Nasabah}

Selain usaha untuk mendapatkan nasabah, usaha lain yang juga sangat penting yaitu bagaimana mempertahankan nasabah yang ada agar tidak berpaling ke pihak Bank lain. Karena jika nasabah ada yang berpaling otomatis jumlah nasabah juga akan berkurang. oleh sebab itu pihak Bank harus selalu menjaga baik nasabah yang ada pada Bank tersebut agar pihak bank tidak kehilangan nasabahnya.

Sebagaimana yang diuraikan Bank Syariah Mandiri Kantor Cabang Pembantu Dumai Sukajadi banyak menawarkan berbagai macam produk seperti pembiayaan dan tabungan. Untuk mengetahui perkembangan jumlah nasabah tabungan BSM pada Bank Syariah Mandiri Kantor Cabang Pembantu Dumai Sukajadi dapat dilihat data sebagai berikut:

Tabel 1 Jumlah Nasabah Tabungan BSM Pada PT Bank Syariah Mandiri Kantor Cabang Pembantu Dumai Sukajadi Dari Tahun 2013-2015

\begin{tabular}{ccc}
\hline Tahun & $\begin{array}{c}\text { Jumlah } \\
\text { Nasabah }\end{array}$ & Persentase \\
\hline 2013 & 3582 & $30.00 \%$ \\
2014 & 4042 & $33.86 \%$ \\
2015 & 4313 & $36.14 \%$ \\
\hline Jumlah & $\mathbf{1 1 9 3 7}$ & $\mathbf{1 0 0 \%}$ \\
\hline
\end{tabular}

Sumber: Data olahan peneliti

Table 2 Perkembangan Saldo Nasabah Pada PT Bank Syariah Mandiri Kantor Cabang Pembantu Dumai Sukajadi Dari Tahun 2013-2015

\begin{tabular}{ccc}
\hline Tahun & Saldo Nasabah & Persentase \\
\hline 2013 & Rp. $12.680 .374 .713,25$ & $28,52 \%$ \\
2014 & Rp. $15.230 .071 .639,52$ & $34,25 \%$ \\
2015 & Rp. $16.555 .283 .106,40$ & $37,23 \%$ \\
\hline Jumlah & Rp. $\mathbf{4 4 . 4 6 5 . 7 2 9 . 4 5 9 , 1 7}$ & $\mathbf{1 0 0 \%}$ \\
\hline
\end{tabular}

Sumber: Data olahan peneliti

Dilihat dari tabel 1 dan tabel 2 perkembangan jumlah nasabah dan saldo nasabah tabungan BSM dari tahun ke tahun mengalami peningkatan yang cukup baik, hal ini disebabkan oleh: (1) Pihak Bank sudah melakukan sosialisasi terhadap masyarakat sehingga masyarakat setempat di area Dumai sudah 
mengenal produk tabungan BSM. (2) Masyarakat sudah mengetahui keberadaan Bank Syariah Mandiri itu sendiri.

Keberadaan produk tabungan BSM ini pada Bank Syariah Mandiri Kantor Cabang Pembantu Dumai Sukajadi ini mendapat dukungan dari masyarakat Dumai itu sendiri. Perkembangan produk tabungan BSM untuk menarik minat nasabah pada PT Bank Syariah Mandiri Kantor Cabang Pembantu Dumai Sukajadi tiap tahunnya mengalami peningkatan yang sangat pesat, karena dari tabel membuktikan jumlah nasabah dari tahun 2013, 2014, dan 2015 jumlah nasabah tabungan BSM pertahunnya rata-rata meningkat $30 \%$. Peningkatan tersebut disebabkan adanya strategi yang di lakukan oleh pihak Bank tersebut berhasil dengan baik walaupun tidak $100 \%$ mendapatkan nasabah dan juga mendapat dukungan oleh masyarakat baik di perkotaan maupun di perdesaan.

\section{KESIMPULAN}

Strategi pemasaran produk tabungan BSM dalam menarik minat nasabah pada PT. Bank Syariah Mandiri Kantor Cabang Pembantu Dumai Sukajadi bahwasannya merupakan langkah untuk memasarkan produknya seperti yang diterapakan oleh PT Bank Syariah Mandiri Kantor Cabang Pembantu Dumai Sukajadi yaitu sosialisasi, penyebaran brosur, buka stand pada saat acara eventevent tertentu, dan juga promosi. Perkembangan produk tabungan BSM PT. Bank Syariah Mandiri Kantor Cabang Pembantu Dumai Sukajadi tiap tahunnya mengalami peningkatan yang sangat pesat, karena dari data yang diperoleh membuktikan bahwa jumlah nasabah dari tahun 2013, 2014 dan 2015 jumlah nasabah tabungan BSM pertahunnya rata-rata meningkat $30 \%$.

\section{DAFTAR PUSTAKA}

Alma, Bukhari dan Juni Prasiansa Donni. 2009. Manajemen Bisnis Syariah, Cetakan Ke-Satu. Bandung: Alfabeta.

Antonio, Muhammad Syafi'i. 2001. Bank Syariah dari Teori ke Praktek, Cetakan Pertama. Jakarta: Gema Insani.

Assauri, Sofjan. 2004. Manajemen Pemasaran, edisi Pertama, Cetakan Ke Tujuh. Jakarta: PT. Raja Grafindo Persada.

At-Tariqi, Abdullah Abdul Husein. 2004. Ekonomi Islam Prinsip Dasar Dan Tujuan. Yogyakarta: Megistra Insania Press.

Batubara, Zakaria. 2015. "Penetapan Harga Jual Beli Dalam Akad Murabahah Pada Bank Syariah”. IQTISHADUNA: Jurnal Ilmiah Ekonomi Kita 4 (2), 163-176.

Dewan Syariah Nasional MUI. 2000. Fatwa Dewan Syariah Nasional. Jakarta.

Hastuti. 2013. "Strategi Bank Syariah Mandiri (BSM) KCP. Bengkalis Dalam Meningkatkan Jumlah Nasabah Tabungan Mudharabah Muthkaqah". Skripsi. STIE Syariah Bengkalis.

Karim, Adiwarman A. 2014. Bank Islam Analisis Fiqih dan Keuangan, Edisi KeLima, Cetakan ke-Sepuluh. Jakarta: PT. Raja Grafindo Persada.

Kartono, Kartini. 2000. Pengantar Ekonomi Research Sosial. Bandung: Alumni. 
Kasmir. 2004. Pemasaran Bank, Edisi Pertama, Cetakan Pertama. Jakarta: Kencana.

Kasmir. 2003. Bank dan Lembaga Keuangan Lainnya, Edisi Keenam, Cetakan Ketujuh. Jakarta: PT. Raja Grafindo Persada.

Mukhtar. 2012. “Aplikasi Produk Tabungan Investa Cendekia PT. Bank Syariah Mandiri Cabang Dumai”. Skripsi. STIE Syariah Bengkalis.

Nurzaman, Muhammad. 2014. "Aplikasi Produk Tabungan BSM Terhadap Akad Mudharabah Muthlaqah Pada PT Bank Syariah Mandiri KCP Bengkalis”. Skripsi. STIE Syariah Bengkalis.

Sjadeinhi, Sutan Remy. 2014. Perbankan Syariah, Edisi Pertama, Cetakan Pertama. Jakarta: Kencana.

Sudarsono, Heri. 2005. Bank dan Lembaga Keuangan Syariah, edisi Ke Dua, Cetakan Ke Tiga. Yogyakarta: Ekonesia.

Sugiyono. 1999. Metode Penelitian Bisnis. Bandung: Alvabet.

Swastha, Basu DH, dan Irawan. 2002. Manajemen Pemasaran Modern, Edisi Kedua, Cetakan Kesepuluh. Yogyakarta: Liberty.

Teguh, Muhammad. 2005. Metodologi Penelitian Ekonomi (Teori dan Aplikasi), Edisi pertama. Jakarta: PT Raja Grafindo Persada.

Umar, Husen. 2005. Metode Penelitian Untuk Skripsi dan Tesis Bisnis. Jakarta: PT. Raja Grafindo Persada. 